\title{
The Filipino Customs Brokers' Perception on the Proposed Customs Modernization and Tariff Act (CMTA) of the Philippines
}

\author{
Roberta L. Riga \\ Asian Institute of Maritime Studies, Philippines
}

Copyright $(\mathrm{C} 2016$ by authors, all rights reserved. Authors agree that this article remains permanently open access under the terms of the Creative Commons Attribution License 4.0 International License

\begin{abstract}
The study focused on the perception of the Filipino Customs Brokers on the proposed Customs Modernization and Tariff Act (CMTA) of the Philippines. Specifically, it established the profile of the customs brokers in terms of years in practice of the profession, number of clients, estimated annual net income and estimated revenue remitted to the Bureau of Customs (BOC). It then determined the level of knowledge of the customs brokers with regards to definition of declarant, responsibilities of declarant, role of third party and exclusion of 'customs broker' under CMTA. It also determined the perception of the customs brokers on the effects of the proposed CMTA to the customs

Commission (PRC) license as customs broker, misunderstanding as to the customs brokers' roles and functions in trade facilitation with the role of third parties, irrelevance of the accredited professional organization of customs brokers and irrelevance of the Professional Regulatory Board for Customs Brokers (PRBCB). Findings revealed that there are no significant differences on the respondents' level of perception on the effects of the proposed CMTA to the customs broker profession when respondents are grouped into their years of practice in the profession, number of clients, estimated annual net income and estimated revenue remittance to the BOC.
\end{abstract} broker profession. Further, it looked into the significant difference on the level of perception of customs brokers on the CMTA when grouped according to their profile variables. The descriptive research design was used in this study utilizing a self-constructed questionnaire as data gathering instrument. Using Slovin's formula, data were gathered from 153 accredited customs brokers transacting at major ports in the Philippines for at least five years. Respondents were selected through convenience sampling. Statistical tools used were percentage, weighted mean and analysis of variance (ANOVA). Most of the respondents were in practice of the customs broker profession for 5 to 10 years, serve 10 to 20 clients, have an estimated annual income of more than one million to five million pesos and have an estimated revenue remittance to the BOC of more than one million to one billion pesos. Findings showed that the customs brokers have high level of knowledge with regards to the definition of declarant, responsibilities of declarant and the role of 'third party' under the proposed CMTA. However, they have low level of knowledge on the exclusion of 'customs broker' on the proposed law. The respondents strongly perceive that the effects of the proposed law to the customs broker profession would be unemployment among employees of existing customs brokerage firms, anxiety among students currently enrolled in the BS Customs Administration (BSCA) program, anxiety among colleges/universities offering the BSCA program, inconsistency with present legislation on customs broker profession, irrelevance of the Professional Regulation
Keywords Filipino Customs Brokers, Perception, Customs Modernization and Tariff Act

\section{Introduction}

In the Philippines, a customs broker is any person who is a bonafide holder of a valid Certificate of Registration/ Professional Identification Card issued by the Professional Regulation Commission [12]. Unlike in other parts of the world, a customs broker in the Philippines is a graduate of a specific baccalaureate program, BS Customs Administration and has passed the Customs Broker Licensure Examination given by the Professional Regulation Commission (PRC). Aside from the Tariff and Customs Code of the Philippines, the customs broker profession is regulated by Republic Act 9280 otherwise known as the Customs Brokers Act of 2004. Thus, Filipino customs brokers have established their name and reputation for quite a long time in handling customs clearance for different types of cargoes for importers, exporters and traders. They are trade facilitation agents acting as intermediaries for the traders in the whole customs process. As quasi-customs agents, they have been able to help the government in the collection of the much needed revenue through the customs duties and taxes from imported and exported goods. They uphold the interest of the 
government by ensuring the collection of the lawful duties and taxes.

The study focused on the perception of the Filipino Customs Brokers on the proposed Customs Modernization and Tariff Act (CMTA) of the Philippines. Specifically, it established the profile of the customs brokers in terms of years in practice of the profession, number of clients, estimated annual net income and estimated revenue remitted to the Bureau of Customs (BOC). It then determined the level of knowledge of the customs brokers with regards to definition of declarant, responsibilities of declarant, role of third party and exclusion of 'customs broker' under CMTA. It also determined the perception of the customs brokers on the effects of the proposed CMTA to the customs broker profession. Further, it looked into the significant difference on the level of perception of customs brokers when grouped according to their profile variables.

With the advent of the Revised Kyoto Convention and the Philippine customs modernization program, the CMTA was proposed. Customs modernization is needed to adapt to the fast changing and evolving international trade. The Filipino customs brokers do not oppose customs modernization. It is just that the proposed CMTA do not clearly recognize the role of customs brokers in trade facilitation and customs administration. In apprehension that the role of customs brokers in the Philippines would be irrelevant once the proposed law would be enforced, the researcher decided to conduct this study.

\section{Literature Review}

Since the ratification of the original Kyoto Convention in 1974, customs administration modernization has become a growing trend in the international arena. The convention was amended in 1999 to keep up with the technological advances and developments in international trade. The following are the purposes of the Revised Kyoto Convention (RKC): develop uniform customs practice and procedure around the world, meet the needs of international trade and customs for facilitation, through simplification of customs procedures and practices, ensure appropriate standards of customs control, enable customs to respond to major changes in business and administrative methods and techniques, and reduce the costs to traders and to governments of customs processing. The harmonization and simplification of customs administration across countries is supposed to remove non-tariff barriers. Ultimately, removal of non-tariff barriers will facilitate and liberalize international trade. [1]

The Philippine government ratified the RKC or the International Convention on the Simplification and Harmonization of Customs Procedures in 2010. According to the BOC, the Philippines has sent a strong message to the international trade community that the government is committed to ensuring that customs procedures will promote trade facilitation and secure movement of goods across territories. Stakeholders also believe that modernization will reduce logistics chain costs and will increase the country's competitiveness in supporting current investments and attracting potential investors. [1]
The WTO ended its Ninth Ministerial Conference in Bali on December 2013, successfully concluding a Trade Facilitation Agreement designed to streamline customs procedures to provide greater predictability, simplicity and uniformity. The agreement is expected to be especially beneficial to U.S. companies, freight forwarders and logistics providers seeking to enter overseas export markets, particularly in developing countries where long delays and inefficiencies at the border raise transaction costs. Launched in 2004, the Trade Facilitation talks produced a document that creates binding commitments among member countries to implement basic, streamlined customs procedures, including: Transparency in publishing all import, export and transit procedures, Opportunity for public comment on proposed regulations, Advance rulings on classification and country of origin, Transparency in inspection, detention and audits, Streamlined entry procedures, including electronic entry, Pre-arrival processing of goods, Promoting risk management, Uniformity in border procedure and management, Promoting Use of Single Window. The requirements are modeled after the customs procedures already in place in the United States, Europe and other developed countries and will take effect in 2015. [2] [3]

Of particular interest to National Customs Brokers \& Forwarders Association of America (NCBFAA), the agreement prohibits any country from introducing the mandatory use of customs brokers after the agreement takes effect. This is intended to address a practice in some Latin American countries, where importations cannot occur without the use of a customs broker, including transactions performed by the importer or (in some countries) his in-house customs broker. The EU was the leading proponent of this provision. Originally, they sought to phase out the mandatory use of customs brokers in those countries, but that language was blocked by Panama. The final wording of the provision in effect "grandfathers" existing policies relating to the use of customs brokers. The agreement also requires that transparent and objective rules be applied in licensing customs brokers. The language, says U.S. Trade Representative, will not affect the law or commercial practices now employed in the U.S. [4]

Article 10 Rule 6 (Used of Customs Broker) of the Agreement on Trade Facilitation of the Bali Ministerial Conference held last December 3-6, 2013, states that "With regards to the licensing of Customs Brokers, Members shall apply rules that are transparent and objective. [3] This only means that the member state of WTO having customs broker with respect to trade facilitation must be given the highest consideration, since customs broker is one of the governments' regulated profession in some countries like the Philippines.

Trade facilitation has its intellectual roots in the fields of logistics and supply chain management. Trade facilitation looks at operational improvements at the interface between business and government and associated transaction costs. Trade facilitation has become a key feature in supply chain security and customs modernization programs. Within the context of economic development it has also come to 
prominence in the Doha Development Round. However, it is an equally prominent feature in unilateral and bilateral initiatives that seek to improve the trade environment and enhance business competitiveness. Reference to trade facilitation is sometimes also made in the context of "better regulation". Propagated ideas and concepts to reforming trade and customs procedures generally resonate around the following themes: Simple rules and procedures, Avoidance of duplication, Memoranda of Understanding (MOU), Alignment of procedures and adherence to international conventions, Trade consultation, Transparent and operable rules and procedures, Accommodation of business practices, Operational flexibility, Public-service standards and performance measures, Mechanisms for corrections and appeals, Fair and consistent enforcement, Proportionality of legislation and control to risk, Time-release measures, Risk management and trader authorizations, Standardization of documents and electronic data requirements, Automation, International electronic exchange of trade data. [5] [6]

As the delegates from the 10-member Association of South East Asian Nations (ASEAN) were winding up its three-day 15th meeting of the ASEAN Customs Procedures and Trade Facilitation and Working Group to draw up the Strategic Plans of Customs Development (SPCD) for the ASEAN Integrated Economy by 2015 at the Traders Hotel last November 7, 2013, the then Philippine Customs Commissioner expressed hope that the Philippine Bureau of Customs (BOC) may after all, be able to catch up with the rate of modernization of its ASEAN counterparts, because of the recent interest of the House Committee on Ways and Means to prioritize the CMTA that would amend the old and outmoded Tariff and Customs Code of the Philippines (TCCP). [7]

In addition, the ASEAN community is now on a high-gear mode to realize its ASEAN Integrated Economy by 2015 and among the major concerns in realizing the One-ASEAN, One Economy is the Information Technology framework that would electronically link the customs agencies of all its member countries. The CMTA bill seek to set international standards in customs operations, and make import trade transactions faster, predictable, efficient and transparent. They also aim to promote and secure international trade, protect and enhance government revenue, prevent smuggling and other fraud against customs and modernize customs and tariff administration. The bills aim to comply with the Revised Kyoto Convention (Convention on the Simplification and Harmonization of Customs Procedures) of the World Customs Organization to which the Philippines is one of the signatories. [8]

Customs Brokers in the United States prepare and submit documentation to notify or obtain clearance from government agencies such as the U.S. Food and Drug Administration, the U.S. Department of Agriculture, and the Fish and Wildlife Service. They also arrange the transshipment (i.e., local delivery) of merchandise via trucking companies. Many customs brokers specialize in certain goods like apparel, perishables, or clearing the crew and manifest of large cargo vessels. Customs brokers can be located at inland ports to clear merchandise sent "in bond", but most are located at major airports and harbors with international traffic. [9] [10]

Customs brokers must pass an examination and background check to become licensed by the U.S. Customs and Border Protection. They are not government employees and should not be confused with "customs officers" (in other countries, however, the two terms may be interchangeable). Customs brokers need to be familiar with the tariff schedule, a listing of duty rates for imported items, and the regulations governing is an importations found in 19 CFR, the Code of Federal Regulations Title 19. To illustrate, a customs broker may need to advise an importer on the marking requirements of the country of origin, or complete paperwork for a clothing shipment subject to quotas and visa requirements. Knowing the requirements of each type of import can avoid costly delays or merchandise seizures. [10]

For customs brokers and clearing agents operating within the European Union, there is no licensing system. The onus is firmly on the importer or exporter to ensure that any party acting on their behalf is in possession of the facts to do so. Article 5 of the current Customs Code, otherwise known as the Council Regulation 2913/1992, deals with representation. This provision allows an importer or exporter to appoint a third party to act on their behalf. The importer or exporter can appoint the third party to act in two capacities, i.e., as a direct representative or as an indirect representative. A direct representative will act on behalf of the importer/exporter but will have no responsibility for the customs debt arising from their actions, whereas an indirect representative will have a joint and several liabilities for the customs debt. In almost all cases, the third party will elect to provide brokerage services on a direct representation basis. As a result the importer or exporter is fully exposed to the risk or error and omission by the customs broker. [11]

Customs Brokers are commonly known as Clearing Agents in Pakistan. They are given license by Customs Authority under VIDE SRO 450(I)/2001 DATED 18-6-2001. In India, customs brokers are licensed by Customs Authority and governed with Customs Brokers Licensing Regulations 2013. In Costa Rica, customs brokers are authorized by Directorate General of Customs (DGA) while university degree requirement is Bachelor of Customs Administration and two years of experience, plus $\$ 10,000$ bail with the first customs. There are heavy fines in case of error or wrong calculation in tariff classification, being one of the more risk professions in Costa Rica. [12]

In Australia, customs brokers are licensed by the Australian Customs Service and some are members of the Customs Brokers and Forwarders Council of Australia. In Canada customs brokers are licensed by the Canada Border Service Agency (Canada Customs) and most are members of the Canadian Society of Customs Brokers. To operate as a customs broker in New Zealand, one needs a Unique User Identification (UUI). UUI Accreditation can be achieved by sitting and passing three exams set by the Customs Brokers and Freight Forwarders Federation of New Zealand Inc (CBAFF). [13] 
In the Philippines, Section 6 of Republic Act 9280 provides that the Customs Broker Profession involves services consisting of consultation, preparation of customs requisite document for imports and exports; declaration of customs duties and taxes; preparation, signing, filing, lodging and processing of import and export entries; representing importers and exporters before any government agency and private entities in cases related to valuation and classification of imported articles; and rendering of other professional services in matters relating to customs and tariff laws its procedures and practices. A customs broker shall also be considered in the practice of the profession if the nature and character of his employment in private enterprises requires professional knowledge in the field of customs and tariff administration. He is also deemed in the practice of customs broker profession if he teaches customs and tariff administration subjects in any university, college or school duly recognized by the Philippine government. [14]

The relationship between a broker and client may begin before the actual importing of goods. A complicated scrutiny of customs duty, tax rates and government trade regulations and quarantine permission may have to be undertaken first. Brokers are trained and licensed to provide consultancy services of the above nature as accuracy is critical to the importer. Due to the brokers' intimate knowledge of the client's business activities, their relationship can be difficult to break. When a broker receives the documents for a job they register it in the company system, then to process a customs entry they must: classify goods in accordance with customs regulations; obtain relevant permits; process the customs entry; and pay duties and taxes on behalf of the importer. After the above is completed and clearance from customs has been given a complete dispatch is made. The customer must be sent invoices for disbursement then the cargo can be taken from the bonded warehouse and delivered to the customer's nominated facility. [15] [16]

In the Philippines, the House Committee on Ways and Means has endorsed for plenary approval the proposed Customs Modernization and Tariff Act (CMTA), which seeks to modernize Customs administration. The Committee, which has jurisdiction on all matters directly and principally relating to the fiscal, monetary and financial affairs of the government including tariff, taxation, revenues, borrowing, credit and bonded indebtedness, explained that House Bill 4788 or CMTA "will also set international standards in Customs operations and make import trade transactions faster, predictable, efficient and transparent, among others." [8] [17]

Under the bill, there are four provisions in the proposed bill that customs brokers deem detrimental to their profession. These are Section 102 (Definition of Terms), Section 109 (Responsibilities of Declarant), Section 110 (Declarant) and Section 1330 (Supervision and Regulation of Third Parties). [17]

On the Definition of Terms in Section 102, what alarms the brokers is not only the provisions mentioned above, but also what has been excluded from the bill. In Section 102, the definition of customs brokers is missing from the list of definition of terms. For the brokers, the exclusion of the definition of their profession in the House Bill signifies that the government fails to recognize the vital role that brokers play in and their significant contributions to effective, efficient, and secure international trade. The brokers fear that ultimately, their profession will not be part of the envisioned modern customs administration in the country. [18]

On the Declarant Provision in Section 110, a declarant is a person who submits a goods declaration to the BOC or in whose name such declaration is made. In practice, the declarant computes the lawful duties and taxes to be imposed on the shipment of cargoes. In the current institutional set-up, cargoes undergo mandatory assessments of licensed customs brokers. Moreover, only customs brokers can sign the import and export entry declarations. However, in the proposed bill, the need for a customs broker is not specified in cases where the declarant is a firm ("juridical person") since such firm may authorize any responsible officer to make the declaration on its behalf. In the proposed bill, anyone including importers and exporters - can now declare their goods or can designate a person to declare the cargo on their behalf. The services of a licensed customs broker would now be considered "optional" as the declarant can be anyone that the importer or exporter deemed capable of making the declaration. Customs brokers consider this provision as another manifestation of an adversarial stand of the House Bill against their profession. They feel that this will not only endanger their jobs but will also jeopardize the processes and integrity of transactions in the BOC. The customs brokers stated that they are experts in the Tariff and Customs Code of the Philippines and have technical knowledge of relevant sections of the National Internal Revenue Code. Letting an untrained person handle the declaration of cargo and computation of duties and taxes can cause costly delays and serve as a non-tariff barrier to efficient trade. Moreover, declarants who are not conversant with Philippine tax laws could make mistakes that may lead to lower tax collections. Hence, they claim that the interest of the state is also in danger because of the likely negative impact of the provision on the BOC's revenue targets. Moreover, they believe that handing over the declaration of goods to unlicensed and unregulated persons could aggravate technical smuggling. [19]

On the Third Party Provision in Section 133, third parties refer to the logistics providers, importers, exporters, customs brokers, carriers, airlines, shipping lines, shipping agents, forwarders, consolidators, port and terminal operators and warehouse operators, among others. In the bill, any of those enumerated and considered as third party is entitled to release the shipment as long as they are entrusted with the job and are authorized by the importer. This is again considered as a threat to the customs broker profession because it means that other parties as enumerated by law can work for the release of imported goods. This provision, according to the Customs Brokers, is an infringement of their rights as a "learned profession" that should be protected by an existing law, i.e., RA 9280 (the Customs Brokers Act of 2004). [19] 


\section{Materials and Methods}

\subsection{Materials}

The descriptive research design was used in this study. A self-constructed questionnaire was utilized as data gathering instrument. Using Slovin's formula, data were gathered from 153 accredited customs brokers transacting at major ports in the Philippines such as Manila International Container Port, Ports of Manila, Batangas, Cebu, and Davao for at least five years. Respondents were selected through convenience sampling. The researcher went to the aforementioned ports to gather data. From October 2013 to March 2014, data were gathered personally by the researcher after which results were tallied, interpreted and analyzed. Statistical tools used were percentage, weighted mean and analysis of variance (ANOVA).

\subsection{Methods}

Data show that most of the respondents ( 60 or 39 percent) had been in the practice of the customs broker profession for 5 to 10 years while 10 or 7 percent had been practicing for over 50 years. This indicates that most of the respondents were young in the profession. As to the number of clients, 52 or 34 percent have 10 to 20 clients while only 17 or 11 percent have over 50 clients. This signifies that customs brokers are distributed among the client importers and exporters in the country and that the competitiveness of the customs brokers in the service results to transfer from one customs broker to another. Most of the customs brokers tend to handle fewer clients to lessen risks and expenses especially when dealing with multinational companies where services are continuous and the volume of shipment is larger.

Findings also indicate that 44 or 29 percent have an estimated annual net income of over one million to five million pesos while 15 or 9 percent disclosed an estimated annual net income of over 10 million pesos. This signifies that the profession is an average income profession.
Sixty-six or 44 percent revealed that they have an estimated revenue remittance to the Philippine BOC of over one million to one billion pesos annually while 6 or 4 percent disclosed an over 10 billion pesos remittance. This revenue remittance is composed of the customs duties due on shipments paid by the clients of the customs brokers to the BOC. These amounts do not include other charges and dues imposed by government agencies and paid by the clients of customs brokers.

As to the level of knowledge, the Filipino customs brokers have high level of knowledge with regards to the definition of declarant. The respondents are highly knowledgeable that under the proposed CMTA, a declarant is defined as a person who makes and submits to the Bureau goods declaration or in whose name such declaration is made and that any person who possesses the right to dispose of the goods shall be entitled to directly act as declarant. In addition, they also know that the provision states that when such person authorizes an agent to make the declaration in his behalf, he can only do so through an accredited customs broker except in case when the declarant is a juridical person in which case it may authorize a responsible officer.

As to the responsibilities of the declarant, the respondents have high level of knowledge that under the proposed CMTA, a declarant shall sign the goods declaration personally or through an employee or officer in case of juridical person or even when assisted by a licensed customs broker who shall likewise sign said goods declaration.

As to third parties transacting with the Bureau in behalf of importers and consignees, the respondents also have high level of knowledge that under the proposed CMTA, those third parties shall be treated equally as if they are themselves the importers or consignees. Third parties as provided in proposed law may refer to, among others, logistics providers, importers, exporters, customs brokers, carriers, airlines, shipping lines, shipping agents, forwarders, consolidators, port and terminal operators and warehouse operators. However, they have low level of knowledge on the exclusion of customs brokers under the proposed law.

Table 1. Perception of Filipino Customs Brokers on the Effects of the Proposed CMTA to their Profession

\begin{tabular}{|l|c|c|}
\hline & Weighted Mean & Verbal Interpretation \\
\hline 1. Closure of existing customs brokerage companies & 3.87 & Perceive \\
\hline 2. Unemployment among employees of existing customs brokerage firms & 4.61 & Strongly Perceive \\
\hline 3. Anxiety among students currently enrolled in the BS Customs Administration (BSCA) program & 4.52 & Strongly Perceive \\
\hline 4. Anxiety among colleges/universities offering the BSCA program & 4.60 & Strongly Perceive \\
\hline 5. Inconsistency with present legislation on customs broker profession & 4.57 & Strongly Perceive \\
\hline 6. Irrelevance of the Professional Regulation Commission (PRC) license as Customs Broker & 4.54 & Strongly Perceive \\
\hline $\begin{array}{l}\text { 7. Misunderstanding as to the customs brokers' role and functions in trade facilitation with the role of } \\
\text { third parties }\end{array}$ & 4.69 & Strongly Perceive \\
\hline $\begin{array}{l}\text { 8. Incoherence with the present computerization program of the Bureau of Customs relative to } \\
\text { accreditation of Customs Brokers }\end{array}$ & 4.10 & Perceive \\
\hline 9. Irrelevance of the accredited professional organization of Customs Brokers & 4.88 & Strongly Perceive \\
\hline 10. Irrelevance of the Professional Regulatory Board for Customs Broker (PRBCB) & 4.69 & Strongly Perceive \\
\hline \multicolumn{1}{|c|}{ Composite Mean } & 4.51 & Strongly Perceive \\
\hline
\end{tabular}

Legend: 5=Strongly Perceive, 4=Perceive, 3=Fairly Perceive, 2=Slightly Perceive, 1-Do not Perceive 
Table 1 presents the perception of the Filipino customs brokers on the effects of the proposed CMTA to their profession. The composite mean of 4.51 means that the respondents strongly perceive that the proposed CMTA would adversely affect the customs broker profession.

The respondents strongly perceive that the effects of the proposed CMTA to the customs broker profession would be unemployment among employees of existing customs brokerage firms, anxiety among students currently enrolled in the BS Customs Administration (BSCA) program, anxiety among colleges/universities offering the BSCA program, inconsistency with present legislation on customs broker profession, irrelevance of the Professional Regulation Commission (PRC) license as customs broker, misunderstanding as to the customs brokers' roles and functions of in trade facilitation with the role of third parties, irrelevance of the accredited professional organization of customs brokers and irrelevance of the Professional Regulatory Board for Customs Brokers (PRBCB). They also perceive that the proposed CMTA would cause closure of existing customs brokerage companies and incoherence with the present computerization program of the Bureau of Customs relative to accreditation of customs brokers.

The respondents revealed that if CMTA would be passed into law, there would be inconsistencies with present legislation on customs broker profession. Currently, Republic Act (RA) 9280 otherwise known as the Customs Broker Act of 2004 is the law that recognizes and regulates the practice of customs broker profession in the Philippines. Under Section 2 of the said law, "It is hereby declared the policy of the State to give priority attention and support to professional zing the practice of customs broker profession in the Philippines which will be beneficial to the country in general and to the economy in particular. Pursuant to the national policy, the government shall provide a program to set up a climate conducive to the practice of the profession and maximize the capability and potential of our Filipino customs brokers." The proposed CMTA has provisions inconsistent with RA 9280. CMTA makes the use of customs brokers an option for the importers and exporters while Section 27 of RA 9280 states that the import entry shall be signed by a customs broker and the consignee/owner/importer under oath based on the covering documents submitted by the importers. With the absence of the specific provisions relating to the practice of the customs broker profession, the PRBCB is no longer relevant since the profession wherein they supervise and regulate would be removed from the roster of professionals. In effect, the PRC license of the customs broker would be unnecessary.

The perceived effects of CMTA could result to closure of existing customs brokerage companies that would result to unemployment among present employees. If not outright closure, they would lose their clients one-by-one leading to retrenchment among their employees. Once this scenario happens, this could cause anxiety among students enrolled in the BSCA program. No one would enroll in a program that would render them jobless and useless in the future. Thus, this would lead to stoppage of the program offering in colleges and universities if enrollees in the program would drop to a significant level. The perceived effects have a domino effect to the entire economic system.

The difference on the level of perception of Filipino Customs Brokers on the effects of CMTA to their profession when grouped according to their profile variables is presented in Table 2.

Since the p-values are higher than 0.05 level of significance, then the computed f-values are found to be not significant. This could also mean that the respondents' level of perception on the effects of the proposed CMTA to the customs broker profession is independent to their years of practice in the profession. There are no significant differences on the respondents' level of perception on the effects of the proposed CMTA to the customs broker profession when respondents are grouped into their profile variables. Hence, the hypothesis is accepted.

Table 2. Difference on the Level of Perception of Filipino Customs Brokers on the Effects of the Proposed CMTA to their Profession when Grouped According to their Profile Variables

\begin{tabular}{|c|c|c|c|}
\hline & & Decision on $\mathrm{H}_{\mathrm{o}}$ & Verbal Interpretation \\
\hline 1. & Closure of existing customs brokerage companies & Failed to Reject & Not Significant \\
\hline 2. & Unemployment among employees of existing customs brokerage firms & Failed to Reject & Not Significant \\
\hline 3. & $\begin{array}{l}\text { Anxiety among students currently enrolled in the BS Customs Administration } \\
\text { (BSCA) program }\end{array}$ & Failed to Reject & Not Significant \\
\hline 4. & Anxiety among colleges/universities offering the BSCA program & Failed to Reject & Not Significant \\
\hline 5. & Inconsistency with present legislation on customs broker profession & Failed to Reject & Not Significant \\
\hline 6. & $\begin{array}{l}\text { Irrelevance of the Professional Regulation Commission (PRC) license as Customs } \\
\text { Broker }\end{array}$ & Failed to Reject & Not Significant \\
\hline 7. & $\begin{array}{l}\text { Misunderstanding as to the customs brokers' role and functions in trade facilitation } \\
\text { with the role of third parties }\end{array}$ & Failed to Reject & Not Significant \\
\hline 8. & $\begin{array}{l}\text { Incoherence with the present computerization program of the Bureau of Customs } \\
\text { relative to accreditation of Customs Brokers }\end{array}$ & Failed to Reject & Not Significant \\
\hline 10 . & Irrelevance of the Professional Regulatory Board for Customs Broker (PRBCB) & Failed to Reject & Not Significant \\
\hline
\end{tabular}




\section{Conclusions}

Most of the respondents were in practice of the customs broker profession for 5 to 10 years, serve 10 to 20 clients, have an estimated annual income of more than one million to five million pesos and have an estimated revenue remittance to the BOC of more than one million to one billion pesos. Findings showed that the customs brokers have high level of knowledge with regards to the definition of declarant, responsibilities of declarant and the role of 'third party' under the proposed CMTA. However, they have low level of knowledge on the exclusion of 'customs broker' on the proposed law. The respondents strongly perceive that the effects of the proposed law to the customs broker profession would be unemployment among employees of existing customs brokerage firms, anxiety among students currently enrolled in the BS Customs Administration (BSCA) program, anxiety among colleges/universities offering the BSCA program, inconsistency with present legislation on customs broker profession, irrelevance of the Professional Regulation Commission (PRC) license as customs broker, misunderstanding as to the customs brokers' roles and functions in trade facilitation with the role of third parties, irrelevance of the accredited professional organization of customs brokers and irrelevance of the Professional Regulatory Board for Customs Brokers (PRBCB). Moreover, they also perceive that if the proposed bill would be passed in its present state, there would be closure of existing customs brokerage companies. Further, some of its provisions are incoherent with the present computerization program of the Philippine Bureau of Customs relative to accreditation of customs brokers. Findings revealed that there are no significant differences on the respondents' level of perception on the effects of the proposed CMTA to the customs broker profession when respondents are grouped into their years of practice in the profession, number of clients, estimated annual net income and estimated revenue remittance to the BOC. Hence, the hypothesis is accepted.

Based on the findings of the study, the researcher recommends that a special forum or Public Hearing be conducted so that provisions can be discussed intensively in order to solicit the point of views of those that might be affected by CMTA such as customs brokers, BSCA students and graduates, colleges and universities offering the BSCA program, Commission on Higher Education and the Professional Regulatory Board for Customs Brokers. In addition, the legislature should be able to augment the discrepancies of the existing law, Republic Act 9280, on the customs broker profession with that of the proposed CMTA. The Filipino customs brokers should have a paradigm shift from mere in-charge of customs clearance to full pledged trade facilitation agents to adapt to the constant changes and development in the field of Customs Administration for the technological advancement of the sector and alignment to international processes. The Accredited Professional Organization of Filipino Customs Brokers should conduct information dissemination of the effects of the proposed CMTA to their profession to enhance their level of awareness on the issue. All associations of customs brokers in the Philippines should be unified in their stand to protect the interest of the majority. Lastly, further studies should be conducted to support the customs broker profession.

\section{Acknowledgements}

Sincere gratitude is hereby extended to the following for the unceasing support until this paper is completely structured:

Foremost, to the author's husband, Bocari P. Riga, for the unconditional love and profound encouragement he has given her; not only in the pursuit of professional excellence but most of all, in the quest of being a better human being. He was a gentleman who truly loved and respected her individuality which was always enriched by his presence. Indeed, this professional success could have been sweeter if he was around - he, whom had been the wind beneath her wings.

Gratitude and appreciation is also extended to her children and wonderful grandchildren, for the unwavering moral and emotional support they have given and for being her backbone to continually face the challenges of life.

To friends and colleagues in the professional practice whose untiring words of encouragements and moral support have been a great source of strength; and to all the panel members of thesis defense for sharing their precious time and positive insights.

Above all, utmost appreciation is given to the Almighty God for His divine intervention in this academic endeavour.

\section{REFERENCES}

[1] The Revised Kyoto Convention: A Pathway to Accession and Implementation, Asia-Pacific Economic Cooperation Publications, 2011, Online available from http://www.invest philippines.info

[2] World Trade Organization Trade Facilitation Agreement Finalized, Online available from http://ibnewsmag.com

[3] 2013 World Trade Organization (WTO) Ministerial Conference Ninth Session, Bali Indonesia, pp. 12-13

[4] Joint Foreign Chambers of the Philippines, Letter to Senator Ralph Recto, Online available from http://www.philstar.com

[5] A. Grainger, Trade Facilitation: A Conceptual Review, Journal of World Trade, ISSN 1011-6702, 45 (1), pp. 39-62, 2011

[6] S. Page, What Happens after Trade Agreements? ODI Project Briefing 12, Overseas Development Institute, 2010

[7] M. Cruz, House gives priority to fiscal bills, Online available from http://manilastandardtoday.com

[8] House Bill 4788, House Panel Endorses Approval of Customs Modernization and Tariff Bill, Online available from https://www.facebook.com 
156 The Filipino Customs Brokers' Perception on the Proposed Customs Modernization and Tariff Act (CMTA) of the Philippines

[9] U.S. CBP, Report to Congress on Integrated Scanning System Pilots (Security and Accountability for Every Port Act of 2006, Section 231, Office of Congressional Affairs, p. 48, 2012

[10] U.S. CBP, Importing into the United States: A Guide for Commercial Importers, U.S. Customs and Border Protection: Trade Facilitation, Enforcement and Security Updated, 2011, Online available from http://www.cbp.gov

[11] T. Cantens, et.al., Customs brokers and informal sectors: A Cameroon Case Study. Policy Research Working Paper, Online available from http://documents.worldbank.org

[12] A. Grainger, Customs and Trade Facilitation: From Concepts to Implementation, World Customs Journal, Volume 2, Number 1 OECD, 2007

[13] Customs and Trade Facilitation: From Concepts to Implementation, Online available from http://worldcustomsj ournal.org

[14] Republic Act 9280, An Act Regulating the Practice of
Customs Brokers Profession in the Philippines, Creating for the Purpose a Professional Regulatory Board for Customs Brokers and Appropriating Funds Therefor, 2004

[15] C. Milner, et. al., Trade Facilitation in Developing Countries, Centre for Research in Economic Development and International Trade, University of Nottingham, Online available from http://www.nottingham.ac.uk

[16] Customs Modernization and Tariff Act Amendments JFC Statement, Online available from http://www.investphilippin es.info

[17] P. S. Romero, House-body-endorses-customs-modernizationand-tariff-act, Online available from http://www.philstar.com

[18] Approval of Bureau of Customs (BOC) Modernization, Tariff Bill Pushed, Sunstar Bacolod, Online available from http://www.sunstar.com.ph

[19] G. M. Llanto, et. al., Customs Brokerage Services and Trade Facilitation: A Review of Regulatory Coherence, Philippine Institute for Development Studies, 2013 